Валентина ЛИТВИН,

orcid.org/0000-0001-6943-792X

аспірант кафедри педагогіки, психології, початкової освіти та освітнього менеджменту Комунального закладу «Харківська гуманітарно-педагогічна академія» Харківської обласної ради

(Харків, Україна) mrs.valentynka@gmail.com

\title{
ТЕОРЕТИКО-МЕТОДОЛОГІЧНІ ПІДХОДИ ДО ОРГАНІЗАЦІЇ ВИХОВАННЯ МАЙБУТНІХ УЧИТЕЛІВ ПОЧАТКОВОЇ ШКОЛИ В ПРОЦЕСІ ФАХОВОЇ ПІДГОТОВКИ
}

\begin{abstract}
У статті проаналізовані теоретико-методологічні підходи до організації виховання майбутніх учителів початкової школи в процесі фахової підготовки. 3'ясовано, щзо загальною проблемою вищої школи України $\epsilon$ пошук найбільш ефективних методик, форм, методів, засобів та шляхів виховання студентської молоді, в контексті нашого дослідження - виховання майбутніх учителів початкової школи. Логіка нашого дослідження передбачає розкриття понять «виховання», «виховуюче навчання», «виховна система» та «виховання майбутніх учителів початкової школи». Визначено, щзо процес виховання - цілісний процес. У ньому органічно поєднані змістова і проиесуальна сторони, де змістова сторона характеризує сукупність виховних иілей, процесуальна сторона - самокерований процес педагогічної взаємодї всіх учасників виховного прочесу. Виховна робота передбачає обтрунтування і реалізацію кониеепії, ичілей, змісту, методів та організаційно-педагогічних форм діяльності студентів ЗВО, спрямованої на розвиток їхньої активності, самовиховання, самоактуалізації та самореалізації. Особливе місце в організащії виховного процесу закладу вищзої освіти належить розв'язанню завдань фахового виховання, метою якого є формування у студентів поваги до обраної спеціальності, вироблення необхідних для неї рис, умінь і навичок, розвиток творчого потениіалу майбутнього фахівия. Вважаємо, щзо головним завданням ЗВО є формування передусім педагога-вихователя, суб'єкта професійної діяльності, який здатний до творчого розв'язання проблеми педагогічного проиесу, має бажсання сприяти вихованню громадянсько свідомої, патріотично налаштованої, професійно компетентної, духовно розвиненої особистості дитини, має сформоване відповідальне ставлення до взаємодї з сім'єю молодшого школяра. Головною метою виховного процесу $3 В О$ $\epsilon$ формування особистості як вищої ичінності, особистості, щзо спроможна самостійно та творчо мислити; а основні завдання виховної роботи у ЗВО полягають у: розвитку високого професіоналізму; розвитку високої загальнопедагогічної культури; формуванні духовності; вихованні відповідальності до реалізації всіх аспектів майбутньої професійної діяльності.
\end{abstract}

Ключові слова: виховання, виховуюче навчання, виховна система, виховання майбутніх учителів початкової иколи.

Valentyna LYTVYN,

Postgraduate Student at the Department of Peda-692X

Psychology, Primary Education and Education Management

Municipal Establishment "Kharkiv Humanitarian Pedagogical Academy" of Kharkiv Regional Council

(Kharkiv, Ukraine) mrs.valentynka@gmail.com

\section{THEORETICAL AND METHODOLOGICAL APPROACHES TO THE ORGANIZATION OF EDUCATION OF FUTURE PRIMARY SCHOOL TEACHERS IN THE PROCESS OF PROFESSIONAL TRAINING}

The article analyzes the theoretical and methodological approaches to the organization of education of future primary school teachers in the process of professional training. It was found that the general problem of higher education in Ukraine is the search for the most effective methods, forms, methods, tools and ways of educating student youth, in the context of our study - the education of future primary school teachers. The logic of our study involves the disclosure of the concepts of "upbringing", "educational training", "educational system" and "education of future primary school teachers". It is determined that the process of education is a holistic process. It organically combines the semantic and procedural aspects, where the semantic side characterizes the set of educational goals, the procedural side - the selfdirected process of pedagogical interaction of all participants in the educational process. Educational work involves 
substantiation and implementation of the concept, goals, content, methods and organizational and pedagogical forms of activity of students of the Free Economic Zone, aimed at the development of their activity, self-education, self-actualization and self-realization. A special place in the organization of the educational process of higher education institution belongs to the solution of professional education, the purpose of which is to form students' respect for the chosen specialty, to develop the necessary traits, skills and abilities, development of creative potential of future specialists. We believe that the main task of university is to form, first of all, a teacher-educator, a subject of professional activity who is able to creatively solve the problem of the pedagogical process, has a desire to promote the education of civic, patriotic, professionally competent, spiritually developed personality. child has formed a responsible attitude to interact with the family of young pupils. The main purpose of the educational process of university is the formation of personality as the highest value, a personality that is able to think independently and creatively; and the main tasks of educational work in university are: development of high professionalism; development of high general pedagogical culture; formation of spirituality; fostering responsibility for the implementation of all aspects of future professional activity.

Key words: upbringing, educational training, educational system, education of future primary school teachers.

Постановка проблеми. Сучасна система виховання в Україні має забезпечувати прилучення молоді до світової культури й загальнолюдських цінностей. Ідеалом виховання є гармонійно розвинена, високоосвічена, соціально активна та національно свідома людина, що наділена глибокою громадянською відповідальністю, високими духовним якостями, родинними та патріотичними почуттями, $є$ носієм кращих надбань національної та світової культури, здатна до саморозвитку й самовдосконалення. Вирішення зазначеного завдання не може бути забезпечено тільки предметною, фаховою підготовкою майбутнього вчителя: освіта відповідатиме вимогам сьогодення і стане повноцінною лише в тому разі, якщо їі зміст визначатиметься виховними цілями.

Виховання громадянина, патріота, фізично й духовно розвиненої людини, професіонала можливе лише в цілісному педагогічному процесі. Формування громадянської позиції особистості, iii національної самосвідомості, ціннісної свідомості, турбота про соціальне благополуччя, духовноморальне та фізичне здоров' $є$ загальною турботою освітян, наукового й педагогічного співтовариства.

Отже, загальною проблемою вищої школи України є пошук найбільш ефективних систем, форм, методів, засобів та шляхів виховання студентської молоді, в контексті нашого дослідження виховання майбутніх учителів початкової школи.

Аналіз досліджень. Сучасна ідеологія виховання віднайшла своє концептуально-правове відображення в Законі України «Про вищу освіту» та низці довгострокових програмних документів: Національній доктрині розвитку освіти України у XXI столітті, Стратегії реформування освіти в Україні / Рекомендації до освітньо-виховної політики; Державній програмі «Патріотичне виховання громадян України»; Державній національній програмі «Освіта» («Україна XXI століття»); Концепції національно-патріотичного виховання молоді тощо. Теоретико-методологічні підходи до організації виховного процесу в ЗВО дослі- джували А. Алексюк, Ш. Амонашвілі, Ю. Бабанський, П. Бабочкін, Н. Басов, І. Бех, С. Бєлозерцев, Л. Боденко, М. Боритко, О. Дорошко, І. Зязюн, І. Ільїнський, В. Лісовський, Л. Лєсохіна, Г. Пономарьова, О. Пономарьов, К. Платова, В. Фортунатов, Г. Шевченко та ін.; аналізу виховної діяльності педагога присвячені праці В. Беспалько, О. Дубасенюк, А. Макаренка, О. Столяренко, Г. Троцко та ін.; теоретичні основи виховання та методики виховної роботи висвітлені в наукових розвідках А. Капської, М. Стельмаховича, В. Сухомлинського, Н. Щуркової та ін.; педагогічні умови організації позааудиторної виховної роботи в закладах вищої освіти вивчали О. Винославська, Т. Куриленко, І. Смирнов, Т. Степура та інші.

Мета статті - схарактеризувати теоретикометодологічні підходи до організації виховання майбутніх учителів початкової школи в процесі фахової підготовки.

Виклад основного матеріалу. Радикальні зміни, що відбуваються в усіх сферах суспільнополітичного й державного життя України, мають важливі й неоднозначні наслідки для іiі розвитку в XXI столітті. В Україні відбувається оновлення громадянського суспільства, реформуються демократичні інститути, складається оновлена система цінностей, яка інтегрує традиційні орієнтації національної культури, ідеали соціальної справедливості, цінності прав і свобод особистості.

У суспільстві формується новий підхід до освітньої системи та виховання студентської молоді. Стратегічні цілі державної політики в галузі освіти знову висувають на одне 3 провідних місць проблеми виховання студентів - однієї 3 найбільш численних і провідних соціальнодемографічних груп сучасної молоді. Саме ця частина молоді незабаром робитиме вирішальний вплив на суспільні процеси, демократичне й економічне оновлення країни, іiі духовну атмосферу, соціально-психологічний клімат і стане джерелом того нового, що має характеризувати Україну як державу другого десятиліття XXI століття. 
Аитвин В. Теоретико-методологічні підходи до організації виховання ...

У зв'язку з демократичним поступом українського суспільства основний шлях у вирішенні цієї важливої проблеми, на наш погляд, полягає в гармонізації особистісних і соціальних інтересів, у забезпеченні комплексу умов для ефективного виховання цілісної, творчої, соціально активної, духовно багатої особистості майбутнього вчителя. Це зумовлює необхідність не тільки об'єктивно оцінювати реальний стан професійної підготовки майбутнього вчителя й констатувати сучасний рівень виховання у вищій освіті, ай визначати дієві механізми, ефективні шляхи і способи цілісного, гармонійного розвитку особистості молодого фахівця - майбутнього педагога, в єдиному, цілісному освітньому процесі закладу вищої освіти (Словник-довідникзпрофесійноїпедагогіки,2006).

Сучасна українська молодь бере участь у модернізації країни, у проведенні реформ. Мінливі умови життя змушують молодих людей пристосовуватися до нових реалій, постійно шукати нові форми ідентичності, виробляти свою життєву позицію, творити свій духовний світ. Тому, беручи участь у цьому глобальному процесі, вітчизняна педагогіка має виконати надзвичайно важливу місію - виховувати в людині духовну культуру, зорієнтовану на найдосконаліші соціокультурні стандарти та загальнолюдські цінності громадянського суспільства (Пономарьова, 2016: 21).

Стає очевидним, що пізнати людину й ті процеси, які відбуваються 3 нею під час виховання, можна лише за умови довіри, поваги, любові, розуміння і творчої взаємодії. Взаємодія стає не тільки ознакою цілісного освітнього процесу, а й умовою його ефективного дослідження. Як зазначає I. Бех, виникає такий методологічний конструкт, як ціннісне ставлення дослідника до суб'єктів педагогічного процесу, що визначає його світоглядну позицію, яка регулює науковий пошук у напряму врахування суб'єктивного, людського фактора (Бех, 1998). Особливо це стосується такого багатовимірного поняття, як виховання.

Саме виховний процес ЗВО покликаний формувати в студентів високу культуру, демократичний світогляд, високі моральні якості, виховувати їх громадянами - патріотами, інтелігентами, творчими й цілеспрямованими фахівцями.

Логіка нашого дослідження передбачає розкриття понять «виховання», «виховуюче навчання», «виховна система» та «виховання майбутніх учителів початкової школи».

Традиційне розуміння терміна «виховання», як визначає А. Кузьмінський, зводиться до чотирьох підходів (Кузьмінський, 2005): соціальний підхід - вплив на людину всієї дійсності - соціуму; педагогічний підхід - цілеспрямована діяльність, що охоплює весь освітній процес; спеціальна педагогічна робота; вирішення завдань, спрямованих на формування морально-вольових якостей, художніх уявлень і смаків.

Як зазначає В. Ягупов: «Виховання - це процес цілеспрямованої, систематичної, організованої і планомірної взаємодії вихователя і вихованця, під час якого відбувається вплив на свідомість, підсвідомість, пізнавальну, емоційно-вольову та мотиваційну сфери вихованця 3 метою формування у нього наукового світогляду, високих моральних, громадських і професійних рис для формування його особистості» (Ягупов, 2002: 424).

I. Підласий зазначає, що виховання у широкому розумінні означає весь процес усебічного розвитку особистості, включаючи навчання і спеціальну виховну роботу з формування соціальних і різноманітних духовних відносин, а у вузькому формування ідеологічних, соціальних, моральних і естетичних відносин (Підласий, 1998: 82).

3. Курлянд вважає, що виховання (Upbringing) це процес цілеспрямованого управління формуванням та розвитком особистості відповідно до вимог суспільства (Курлянд, 2005).

Мета виховання - це формування соціально активної, гуманістично спрямованої особистості, яка у своїй життєдіяльності керується загальнолюдськими (честь, совість, людська гідність, соціальна справедливість) і культурно-національними (працелюбність, волелюбність тощо) цінностями. Виховання - це процес, що веде до певних змін, цілеспрямоване управління і керівництво розвитком особистості, взаємодія всіх суб' єктів і об' єктів педагогічного процесу, розвиваюча діяльність.

В українському педагогічному словнику (Гончаренко, 1997: 53) термін «виховання» розглядається як процес цілеспрямованого, систематичного формування особистості, зумовлений законами суспільного розвитку, дією багатьох об'єктивних і суб'єктивних факторів. У широкому розумінні виховання - це вся сума впливів на психіку людини, спрямованих на підготовку іiі до активної участі у виробничому, громадському й культурному житті суспільства. Сюди входить як спеціально організований вплив виховних закладів, так і соціально-економічні умови, що діють певною мірою стихійно. У вузькому розумінні слова виховання $\epsilon$ планомірним впливом батьків і школи на вихованця. Засобом виховання $є$ насамперед приклад, який вихователь подає вихованцеві, потім - наказ (вимога й заборона), переконання, привчання й навчання. Виховання поширюється на тіло, душу й дух і ставить завданням утворення 
із задатків і здібностей, що розвиваються, гармонійного цілого, а також набуття підростаючим вихованцем сприятливих для нього самого та для суспільства душевно-духовних установок стосовно інших людей, сім'ї, народу, держави тощо.

Сучасні науковці розглядають виховання як суспільне явище, процес, результат, цінність, систему, взаємодію тощо. Аналіз дефініції «виховання〉 подано в таблиці 1.

Сучасна вітчизняна педагогічна теорія розглядає процес виховання у єдності з навчанням, його називають «виховуючим навчанням»; це передбачає не заперечення специфіки навчання й виховання, а глибоке пізнання змісту функцій, організації, засобів форм і методів навчання й виховання.

Термін «виховуюче навчання» запроваджено в педагогіку Й. Гербартом, який вважав, що навчання $\epsilon$ основним засобом виховання. К. Ушинський розглядав навчання як важливий засіб морального виховання.

С. Гончаренко визначає виховуюче навчання як організацію процесу навчання, за якої забезпечується органічний взаємозв'язок між набуттям знань, умінь і навичок, засвоєнням досвіду творчої діяльності й формуванням емоційно-ціннісного ставлення до світу, один до одного, до навчального матеріалу (Гончаренко, 1997: 53-54).

Дбаючи про створення оптимальних умов для виховної роботи, не варто виносити завдання виховання за рамки навчального процесу. Треба зважати на дієвість і впливовість великого спек- тру форм діяльності, які сприяють формуванню всебічно розвиненої особистості. Це навчальні заняття, практика, наукові гуртки, творчі студії, екскурсії, походи, різноманітні форми і види суспільно корисної праці тощо.

Слід наголосити, що процес виховання - цілісний процес. У ньому органічно поєднані змістова і процесуальна сторони. На думку М. Фіцули, змістова сторона характеризує сукупність виховних цілей, процесуальна сторона - самокерований процес педагогічної взаємодії всіх учасників виховного процесу (Фіцула, 1997: 19).

Виховна робота передбачає обгрунтування i реалізацію концепції, цілей, змісту, методів та організаційно-педагогічних форм діяльності студентів ЗВО, спрямованої на розвиток їхньої активності, самовиховання, самоактуалізації та самореалізації. Вважаємо, що виховання майбутніх учителів початкової школи повинно відбуватися у цілеспрямованій та систематично організованій виховній системі.

Г. Пономарьова зазначає, що виховна система освітнього закладу-цесукупність взаємопов'язаних компонентів, складник його цілісної соціальнопедагогічної структури (Пономарьова, 2014).

На думку дослідниці С. Авдєєвої, для виховної системи характерні такі ознаки: цілі виховної системи є особистісно значущими як для дорослих, так і для дітей; спільна життєдіяльність педагогів, учнів і батьків, що грунтується на засадах гуманістичних цінностей, міжсуб'єктної взаємодії,

Таблиця 1

Характеристика змісту поняття «виховання»

\begin{tabular}{|c|l|c|}
\hline $\begin{array}{c}\text { № } \\
\text { 3/п }\end{array}$ & \multicolumn{1}{|c|}{ 3міст поняття } & \multicolumn{1}{|c|}{ Дослідник } \\
\hline 1. & $\begin{array}{l}\text { Виховання - це формування особистісних цінностей, що характеризують духовно } \\
\text { розвинену, виховану людину (Бех, 1998); }\end{array}$ & I. Бех \\
\hline 2. & $\begin{array}{l}\text { Виховання - це ціннісно спрямований процес людинотворення, зорієнтований } \\
\text { насамперед на розвиток духовно-ціннісної сфери самосвідомості (Шевченко, 2012); }\end{array}$ & Г. Шевченко \\
\hline 3. & $\begin{array}{l}\text { Виховання - це процес, спрямований на активну різноманітну діяльність особис- } \\
\text { тості учня, його самореалізацію й самоствердження в цій діяльності (Мойсеюк, } \\
\text { 2001: 401); }\end{array}$ & Н. Мойсеюк \\
\hline 4. & $\begin{array}{l}\text { Виховання як педагогічне явище виступає невід'ємною частиною цілісного освіт- } \\
\text { наук і відповідних їм умінь і навичок, закладаються основи світогляду, розвива- } \\
\text { ються пізнавальні сили, творчі здібності й емоційно-вольова сфера особистості, } \\
\text { формуються моральні якості і звички поведінки (Пономарьова, 2016: 24); }\end{array}$ & Г. Пономарьова \\
\hline 5. & $\begin{array}{l}\text { Виховання - це процес цілеспрямованого формування світогляду, морального } \\
\text { обличчя, естетичного смаку, фізичного розвитку (Кращенко, 2012: 35); }\end{array}$ & Ю. Кращенко \\
\hline 6. & $\begin{array}{l}\text { Виховання: у широкому суспільному значенні - забезпечення передачі з покоління } \\
\text { до покоління накопиченого соціально-культурного досвіду, цінностей; у широкому } \\
\text { педагогічному значенні - процес цілеспрямованого формування особистості в умо- } \\
\text { вах спеціально організованої виховної системи; у вузькому педагогічному значенні } \\
- \text { цілеспрямована взаємодія вихователів і вихованців, спрямована на формування } \\
\text { певних якостей, властивостей, відносин людини (Лозова, Троцко, 2002: 24). }\end{array}$ & $\begin{array}{l}\text { В. Лозова, } \\
\text { Г. Троцко }\end{array}$ \\
\hline
\end{tabular}


взаємоповаги, довіри й доброзичливості; педагогічна діяльність, спрямована на забезпечення умов для вияву і розвитку індивідуальності й суб' єктності особистості дитини; дорослі й діти відчувають захищеність, комфортність, задоволеність життєдіяльністю в навчальному закладі (Авдєєва, 2012).

У статті «Виховна система школи творчого зростання особистості» С. Авдєєва (Авдєєва, 2012) обгрунтовує виховну систему як педагогічну концепцію виховання, що охоплює весь педагогічний процес, інтегруючи навчальні заняття, позаурочне життя дітей, різноманітну діяльність і спілкування, вплив соціального, предметно-естетичного середовища. Виховна система $є$ відкритою, здатною до саморегуляції, постійного розвитку, має складну структуру і складається 3 компонентів, скріплених системними зв'язками.

У дисертації Г. Пономарьової «Система виховної роботи у вищих педагогічних навчальних закладах» схарактеризовані умови ефективності виховної роботи зі студентами, серед яких $\epsilon$ диференціація виховних впливів із урахуванням життєвого й соціального досвіду студентів, що накопичується від курсу до курсу, освітнє, культурне, естетичне творче середовище педагогічного закладу вищої освіти, сучасна матеріальнотехнічна база й така виховна інфраструктура, завдяки якій можливо задовольнити різноманітні інтереси, запити студентів, створити комплекси виховних заходів (Пономарьова, 2016).

Також Г. Пономарьовою обгрунтовані теоретико-методологічні засади організації системи виховної роботи у педагогічних закладах вищої освіти, які відповідають сучасним тенденціям виховання майбутнього педагога й охоплюють такі рівні: методологічний (концептуальну ідею, закономірності, принципи, категорії, підходи); теоретичний (зміст, фактори, функції, умови, технології); методичний (методики діагностики та моніторингу), що забезпечують результативність системи виховної роботи в педагогічних 3ВО; визначено критерії й показники ефективності системи виховної роботи, за якими забезпечується високий рівень вихованості майбутніх педагогів: мотиваційно-ціннісний (пріоритет духовноморальних ціннісних орієнтацій; умотивованість до морально відповідальної поведінки й саморозвитку; прагнення до творчої та професійної самореалізації й самовдосконалення), інтелектуальнодуховний (свідоме обрання фаху та професійні якості; рівень соціальних і правових знань; рівень знань про національну та світову культуру), діяльнісно-рефлексивний (гуманістична спрямованість поведінки й активна життєва позиція; соціокультурна діяльність; критичне ставлення до власних вчинків і соціальна відповідальність), схарактеризовані рівні (високий, середній і низький); розроблено духовно орієнтовану та професійно спрямовану модель системи виховної роботи у педагогічних ЗВО, що складається 3 цільового (соціальне замовлення, мета, завдання, нормативно-правове забезпечення та теоретико-методологічні засади (закономірності, принципи, функціï), змістовного (організаційно-педагогічні умови, зміст виховної роботи: аудиторна, позаудиторна, педагогічна практика, самовиховання), технологічного (методи, форми, засоби, технології) та результативного блоків (критерії, показники та ix змістові рівні) (Пономарьова, 2016: 6).

Аналізу виховної системи вищих навчальних закладів присвячена монографія Л. Бєлової «Виховна система ВНЗ: теорія і практика» (Бєлова, 2004). Головним призначенням виховної системи $є$ педагогічне забезпечення розвитку особистості, яку вона розглядає як упорядковану цілісну сукупність компонентів, взаємодія й інтеграція яких визначає здатність навчального закладу цілеспрямовано й ефективно розвивати особистість. Цю здатність науковець уявляє як: спроможність діагностувати розвиток особистості студента, студентського колективу; спроможність сформувати й обгрунтувати мету виховного процесу; спроможність організувати життєдіяльність співтовариства молоді й дорослих, сприяти максимальній самореалізації суб'єктів виховного процесу в спільній діяльності, взаємодії; спроможність інтегрувати зусилля суб'єктів виховного процесу; спроможність створити ефективне виховне середовище, здатність до самореалізації, аналізу й оцінки результативності виховного процесу (Бєлова, 2004).

Т. Осипова (Осипова, 2001) зазначає, що головною метою виховної системи педагогічного 3ВО $€$ : виховання майбутніх учителів як носіїв педагогічної культури, спеціалістів, що несуть гуманістичні ідеали, цивілізовані норми стосунків між людьми, відношення до народу, вітчизни, до самих себе; обов'язок педагогічного ЗВО - готувати молодих спеціалістів, що володіють знаннями на рівні сучасних вимог, уміють навчати та виховувати учнів. Стержнем виховної роботи $\epsilon$ виховання, спрямоване на формування світогляду на основі наукових знань.

Виховання майбутніх учителів початкової школи має певні особливості, які ми повинні розглянути. Майбутній учитель $є$ реалізатором державної політики щодо розвитку та формування 
майбутнього покоління. Від рівня підготовки залежить його професіоналізм і якість професійної діяльності. Важливого значення в особистісному становленні майбутнього вчителя набуває власне загальнопедагогічна підготовка та виховна робота як складники всієї фахової підготовки.

Сьогодення вимагає яскравої особистості майбутнього вчителя початкової школи, який глибоко володіє досягненнями наук про людину та закономірностями іiі розвитку, новими педагогічними технологіями й мистецтвом спілкування, $\mathrm{\epsilon}$ транслятором національних культурно-історичних традицій і духовних цінностей. До дітей має прийти агент позитивних змін, людина-лідер, яка може вести за собою, яка любить свій предмет, яка його фахово викладає.

Таким чином, головним завданням 3ВО є формування насамперед педагога-вихователя, суб'єкта професійної діяльності, який здатний до творчого розв'язання проблеми педагогічного процесу, має бажання сприяти вихованню громадянсько свідомої, патріотично налаштованої, професійно компетентної, духовно розвиненої особистості дитини, має сформоване відповідальне ставлення до взаємодії з сім'єю молодшого школяра.

3 огляду на це значний інтерес представляе дослідження Л. Пелех, у якому визначено чотири основні напрями організації виховного процесу в контексті підготовки майбутніх учителів початкової школи, а саме: формування особистості майбутнього вчителя має відбуватися як у процесі аудиторної роботи, так і в позааудиторній діяльності; обов'язковим складником цілісної концепції педагога $є$ професійне самовиховання; формування всебічно розвиненої особистості шляхом активізації в різних сферах діяльності - соціальній, політичній, науковій, художній; упровадження масових форм, методів і засобів виховної роботи в діяльність педагогічного ЗВО (Пелех, 2000).

Основними компонентами виховного процесу, за М. Рожковим та Л. Байбородовою, є: цільовий (передбачає визначення мети); змістовний (включає в себе основні напрями виховної діяльності); операційно-діяльнісний (визначає комплекс педагогічних засобів для розв'язання мети, завдань); аналітико-результативний (у процесі реалізації якого виявляються зміни в рівні вихованості індивіда) (Рожков, Байбородова, 2000).

У словнику-довіднику з професійної педагогіки зазначено, що виховна робота в педагогічному В3О (Educational work at Pedagogical Higher Institution) - це робота, яка грунтується на ідеях цілісної підготовки вчителя, в якій процеси виховання та навчання майбутніх педагогів органічно поєднані та мають гуманістичний характер: освітній процес у педагогічному ЗВО повинен забезпечувати умови для самореалізації особистості, сприяти максимальному розкриттю її здібностей та професійних інтересів, формувати національну самосвідомість і людську гідність, гуманність та толерантність у ставленні до людини; виховання майбутніх учителів здійснюється на засадах всебічного та різноманітного залучення їх до самоврядування, забезпечує розвиток їх активності, громадської свідомості, відповідальності за долю підростаючих поколінь; виховний процес сприяє формуванню професійно-педагогічної спрямованості, професійній усталеності майбутніх учителів, розвитку їх педагогічних здібностей та потреби до постійного самовдосконалення; система виховання обіймає всі види виховної роботи та спрямовується на формування активної позиції особистості вчителя (Словник-довідник з професійної педагогіки, 2006).

Ми вважаємо, що основними напрямами та змістом виховної роботи в процесі фахової підготовки майбутніх учителів початкової школи $є$ : вивчення особистості здобувачів вищої освіти; створення оптимальних умов для швидкої адаптації і саморозвитку особистості студента; формування професійно-педагогічної спрямованості особистості; виховання відповідального ставлення та любові до професії вчителя; формування загальнопедагогічної культури майбутнього вчителя; виховання активної громадянської позиції; виховання національної самосвідомості; виховання інтелектуальної культури; формування умінь і навичок культури розумової праці; виховання потреби до самоосвіти; моральне виховання; формування духовної культури; гуманного ставлення до людей; формування екологічної та економічної культури; повага та толерантне ставлення до людей іншої національності, які живуть в Україні; виховання майбутніх учителів як носіїв гуманних взаємин між людьми різних національностей, здатних нести національну свідомість своїм вихованцям; виховання відповідального ставлення до взаємодії з батьками в освітньому просторі 33СО; формування політичної та правової культури; виховання естетичної культури майбутнього вчителя в усіх формах її вияву та готовності нести таку культуру до школи своїм учням; виховання фізичної культури; розвиток студентського самоврядування в організації виховної роботи в групах, студентському гуртожитку; науково-педагогічна та методична підготовка молодих викладачів, кураторів до виховної роботи зі студентами; забезпечення зв'язку щодо цілей i 
завдань виховної системи; організаційна робота щодо виконання плану виховної роботи ЗВО тощо.

Висновки. Виховна робота передбачає обгрунтування і реалізацію концепції, цілей, змісту, методів та організаційно-педагогічних форм діяльності студентів 3ВО, спрямованої на розвиток їхньої активності, самовиховання, самоактуалізації та самореалізації. Особливе місце в організації виховного процесу закладу вищої освіти належить розв'язанню завдань фахового виховання, метою якого $є$ формування у студентів поваги до обраної спеціальності, вироблення необхідних для неї рис, умінь і навичок, розвиток творчого потенціалу майбутнього фахівця. Головною метою виховного процесу ЗВО $є$ формування особистості як вищої цінності, особистості, що спроможна самостійно та творчо мислити; а основні завдання виховної роботи у ЗВО полягають у: розвитку високого професіоналізму; розвитку високої загальнопедагогічної культури; формуванні духовності; вихованні відповідальності до реалізації всіх аспектів майбутньої професійної діяльності.

\section{СПИСОК ВИКОРИСТАНИХ ДЖЕРЕЛ}

1. Авдєєва С. В. Виховна система школи творчого зростання особистості. Виховна робота в школі. 2012. № 8. С. 20-34.

2. Бех І. Д. Особистісно-зорієнтоване виховання : наук.-метод. посіб. Київ, 1998. 204 с.

3. Бєлова Л. О. Виховна система ВНЗ: питання теорії і практики : монографія. Харків. : Вид-во НУА, 2004. 264 с.

4. Гончаренко С. У. Український педагогічний словник. Київ: Либідь, 1997. 373 с.

5. Кращенко Ю. П. Виховання лідерських якостей майбутніх учителів у системі студентського самоврядування : дис. ... канд. пед. наук : 13.00.07. Полтава, 2012. 276 с.

6. Кузьмінський А. І. Педагогіка вищої школи : навч. посіб. Київ : Знання, 2005. 486 с.

7. Лозова В. І., Троцко Г. В. Теоретичні основи виховання і навчання : навчальний посібник. Харків : «ОВС», 2002. $400 \mathrm{c}$

8. Мойсеюк Н. Є. Педагогіка : навч. посіб. 3-тє вид., допов. Київ : ВАТ «КДНК», 2001. 607 с.

9. Осипова Т. Ю. Формування професійно-орієнтованої особистості майбутнього вчителя : дис. ... канд. пед. наук : 13.00.04. Одеса : ПДПУ ім. К. Д. Ушинського, 2001. 248 с.

10. Педагогіка вищої школи : навч. посіб. / за ред 3. Н.Курлянд. 2-ге вид., перероб. і доп. Київ : Знання, 2005. 399 с.

11. Пелех Л. Р. Перспективи розвитку масових виховних заходів у вищих навчальних закладах нового типу. Гуманізаиія навчально-виховного процесу: наук.-метод. зб. 2000. Вип. Х. С. 54-61.

12. Підласий І. П. Діагностика та експертиза педагогічних проектів : навч. посібник. Київ : Україна, 1998. 343 с.

13. Пономарьова Г. Ф. Система виховної роботи у вищих педагогічних навчальних закладах : автореф. дис. ... докт. пед. наук : 13.00.07. Київ, 2016. 40 с.

14. Пономарьова Г. Ф. Теоретичний аналіз формування системи управління сучасним вищим навчальним закладом. Інноваційний підхід в управлінні навчальними закладами : зб. матеріалів наук.-практ. конф. Житомир : Вид-во ЖДУ ім. І. Франка, 2014. С. 161-163.

15. Пономарьова Г.Ф. Система виховної роботи у вищих педагогічних навчальних закладах : дис. ... докт. пед. наук : 13.00.07. Севєродонецьк, 2016. 540 с.

16. Рожков М. І., Байбородова Л. В. Організація виховного процесу в школі. 2000. С. 18-19.

17. Словник-довідник з професійної педагогіки / за ред. А. В. Семенової. Одеса : Пальміра, 2006. 221 с.

18. Фіцула М. М. Педагогіка : навч. посібник для студентів вищих пед. закладів освіти. Тернопіль, 1997. 192 с.

19. Шевченко Г. П. Тенденції модернізації виховного процесу у вищій школі. Педагогічна і психологічна науки в Україні : зб. наук. пр. : в 5 т. Київ : Педагогічна думка, 2012. Т. 5: Вища школа. С. 241-254.

20. Ягупов В. В. Педагогіка : навч. посібник. Київ : Либідь, 2002. 560 с.

21. Яхнін Я. К. Сучасні підходи до якості освіти. Київ : Наукова думка, 2010. 143 с.

\section{REFERENCES}

1. Avdieieva S. V. Vykhovna systema shkoly tvorchoho zrostannia osobystosti. [Educational system of the school of creative growth of the individual]. Vykhovna robota v shkoli. 2012. № 8. S. 20-34. [in Ukrainian].

2. Bekh I. D. Osobystisno-zoriientovane vykhovannia [Personality-oriented education] : nauk.-metod. posib. Kyiv, 1998. 204 s. [in Ukrainian].

3. Bielova L. O. Vykhovna systema VNZ: pytannia teorii i praktyky [Educational system of higher education institutions: questions of theory and practice] : monohrafiia. Kharkiv. : Vyd-vo NUA, 2004. 264 s. [in Ukrainian].

4. Honcharenko S. U. Ukrainskyi pedahohichnyi slovnyk [Ukrainian pedagogical dictionary]. Kyiv: Lybid, 1997. 373 s. [in Ukrainian].

5. Krashchenko Yu. P. Vykhovannia liderskykh yakostei maibutnikh uchyteliv u systemi studentskoho samovriaduvannia [Education of leadership qualities of future teachers in the system of student self-government] : dys. ... kand. ped. nauk : 13.00.07. Poltava, 2012. $276 \mathrm{~s}$. [in Ukrainian].

6. Kuzminskyi A. I. Pedahohika vyshchoi shkoly [Pedagogy of high school] : navch. posib. Kyiv : Znannia, 2005. 486 c. [in Ukrainian].

7. Lozova V. I., Trotsko H. V. Teoretychni osnovy vykhovannia i navchannia [Theoretical foundations of education and training] : navchalnyi posibnyk. Kharkiv : "OVS", 2002. 400 s. [in Ukrainian]. 
8. MoiseiukN. Ye.Pedahohika[Pedagogy] : navch.posib. 3-tievyd., dopov. Kyiv:VAT“KDNK”, 2001.607 s. [in Ukrainian].

9. Osypova T. Yu. Formuvannia profesiino-oriientovanoi osobystosti maibutnoho vchytelia [Formation of professionally-oriented personality of the future teacher] : dys. ... kand. ped. nauk : 13.00.04. Odesa : PDPU im. K. D. Ushynskoho, 2001. 248 s. [in Ukrainian].

10. Pedahohika vyshchoi shkoly [Pedagogy of high school] : navch. posib. / za red Z. N.Kurliand. 2-he vyd., pererob. i dop. K.: Znannia, 2005. 399 c. [in Ukrainian].

11. Pelekh L. R. Perspektyvy rozvytku masovykh vykhovnykh zakhodiv u vyshchykh navchalnykh zakladakh novoho typu. [Prospects for the development of mass educational activities in higher educational institutions of a new type]. Humanizatsiia navchalno-vykhovnoho protsesu: nauk.-metod. zb. 2000. Vyp. X. S. 54-61. [in Ukrainian].

12. Pidlasyi I. P. Diahnostyka ta ekspertyza pedahohichnykh proektiv [Diagnosis and examination of pedagogical projects] : navch. posibnyk. Kyiv : Ukraina, 1998. 343 s. [in Ukrainian].

13. Ponomarova H. F. Systema vykhovnoi roboty u vyshchykh pedahohichnykh navchalnykh zakladakh [The system of educational work in higher pedagogical educational institutions] : avtoref. dys. ... dokt. ped. nauk : 13.00.07. Kyiv, 2016.40 s. [in Ukrainian].

14. Ponomarova H. F. Teoretychnyi analiz formuvannia systemy upravlinnia suchasnym vyshchym navchalnym zakladom. [Theoretical analysis of the formation of the management system of a modern higher education institution]. Innovatsiinyi pidkhid v upravlinni navchalnymy zakladamy : zb. materialiv nauk.-prakt. konf. Zhytomyr : Vyd-vo ZhDU im. I. Franka, 2014. S. 161-163. [in Ukrainian].

15. Ponomarova H. F. Systema vykhovnoi roboty u vyshchykh pedahohichnykh navchalnykh zakladakh [The system of educational work in higher pedagogical educational institutions] : dys. ... dokt. ped. nauk : 13.00.07. Sievierodonetsk, 2016. 540 s. [in Ukrainian].

16. Rozhkov M. I., Baiborodova L. V. Orhanizatsiia vykhovnoho protsesu v shkoli.[Organization of the educational process at school]. 2000. S. 18-19. [in Ukrainian].

17. Slovnyk-dovidnyk z profesiinoi pedahohiky [Dictionary-reference book on professional pedagogy] / za red. A. V. Semenovoi. Odesa : Palmira, 2006. 221 s. [in Ukrainian].

18. Fitsula M. M. Pedahohika [Pedagogy] : navch. posibnyk dlia studentiv vyshchykh ped. zakladiv osvity. Ternopil, 1997. 192 s. [in Ukrainian].

19. Shevchenko H. P. Tendentsii modernizatsii vykhovnoho protsesu u vyshchii shkoli. [Trends in the modernization of the educational process in higher education]. Pedahohichna i psykholohichna nauky v Ukraini : zb. nauk. pr. : v 5 t. Kyiv : Pedahohichna dumka, 2012. T. 5: Vyshcha shkola. S. 241-254. [in Ukrainian].

20. Iahupov V. V. Pedahohika [Pedagogy] : navch. posibnyk. K.: Lybid, 2002. 560 s. [in Ukrainian].

21. Iakhnin Ya. K. Suchasni pidkhody do yakosti osvity. [Modern approaches to the quality of education]. Kyiv : Naukova dumka, 2010. 143 s. [in Ukrainian]. 